\title{
Arginine and Mixed Amino Acids Increase Protein Accretion in the Growth-Restricted and Normal Ovine Fetus by Different Mechanisms
}

\author{
HENDRINA A. DE BOO, PIERRE L. VAN ZIJL, DESIRÉE E.C. SMITH, WILLEM KULIK, \\ HARRIE N. LAFEBER, AND JANE E. HARDING
}

The Liggins Institute [H.A.d.B., P.L.v.Z., J.E.H.], Faculty of Medicine and Health Science, University of Auckland, Auckland, New Zealand; and Departments of Pediatrics [H.A.d.B., H.N.L.] and Clinical

Chemistry [D.E.C.S., W.K.], Vrije Universiteit Medisch Centrum, 1081 HV, Amsterdam, The Netherlands

\section{ABSTRACT}

Protein metabolism may be perturbed in intrauterine growth restriction (IUGR). Arginine is indispensable for growth and nitrogen balance in young mammals. Fetuses with IUGR therefore may benefit from arginine supplementation. The purpose of this study was to determine 1) the effects of IUGR on protein metabolism in the ovine fetus and 2) the effects of arginine or mixed amino acid (AA) infusion on protein metabolism in these fetuses. Pregnant ewes and their fetuses were catheterized at $110 \mathrm{~d}$ gestation and randomly assigned to control or IUGR groups. IUGR was induced by repetitive placental embolization. Parameters of fetal protein metabolism were determined from [ring- ${ }^{2} \mathrm{H}_{5}$ ]phenylalanine kinetics at baseline and in response to a 4-h infusion of either arginine or an isonitrogenous AA mixture. There were no differences in protein metabolism between control and IUGR groups either at baseline or in response to arginine or AA treatment. Both arginine and AA infusion increased fetal protein accretion in both groups. Arginine did this by decreasing protein turnover, synthesis, and breakdown. AAs increased protein turnover and synthesis while decreasing protein breakdown. AA infusion resulted in a significantly higher increase in protein accretion than arginine infusion. Thus, in the ovine fetus, placental embolization has no clear effect on protein metabolism. Arginine and AAs both stimulate protein accretion but do so in distinctly different ways. Mixed AA infusion has a greater effect on protein accretion than arginine alone and therefore may be a better strategy for stimulating fetal growth. (Pediatr Res 58: 270-277, 2005)
AA, amino acid
Abbreviations
FA, fetal artery
FV, fetal vein
HIBF, hind limb blood flow
IUGR, intrauterine growth restriction
NB, net tracer balance
NO, nitric oxide
TTR, tracer/tracee ratio
UA, uterine artery
UOV, utero-ovarian vein
$\mathbf{U V}$, umbilical vein

Intrauterine growth restriction (IUGR) is a major cause of perinatal mortality and morbidity $(1,2)$. Although there are many possible causes, the key feature of IUGR is impaired fetal growth and, hence, by inference, impaired protein accretion. However, there are few data describing the alterations in protein metabolism that must underlie IUGR.

In the IUGR human neonate, the few studies available are conflicting (3-5). Protein accretion rates are reported to be

Received July 14, 2004; accepted January 14, 2005.

Correspondence: Jane E. Harding, FRACP, DPhil, The Liggins Institute, Faculty of Medicine and Health Science, University of Auckland, Private Bag 92019, Auckland, New Zealand; e-mail: j.harding@auckland.ac.nz.

This project was supported by grants from the Nutricia Research Foundation and the Health Research Council of New Zealand. H.d.B. received a scholarship from the Ter Meulen Fonds.

DOI: 10.1203/01.PDR.0000169977.48609.55 normal, although both increased $(3,4)$ and reduced $(5)$ protein synthesis and turnover have been reported. A previous study on protein kinetics in the ovine fetus in which growth was restricted by heat stress showed no significant changes in protein synthesis, breakdown, or accretion (6). However, a number of reports provide indirect evidence of altered protein metabolism in human fetuses with IUGR. In human pregnancies that are complicated with IUGR, fetal plasma AA concentrations are reduced $(7,8)$, and this persists after birth (9). Concentrations of most essential AAs are lower, particularly those of the branched-chain AAs valine, isoleucine, and leucine $(7,9)$. The maternal plasma AA concentrations are higher than in uncomplicated pregnancies and often not significantly different from nonpregnant controls (8).

There is also indirect evidence of impaired urea production in association with IUGR. Plasma and urinary urea levels are 
reduced and ammonia levels are elevated in both human neonates and guinea pig fetuses with $(10,11)$. In the neonate with IUGR, ammonia levels increased with increasing protein intake (12). In the guinea pig fetuses with IUGR, urea cycle enzyme activities in the liver were markedly reduced. This resulted in significantly lower urea production rates, whereas the ammonia concentration in liver slices were 16-fold higher than in the non-growth restricted controls (11). As urea production is the final common pathway of protein metabolism, altered urea production suggests a limited capacity to process excess nitrogen.

To try to establish optimal postnatal growth, neonates with IUGR are usually fed the same high-protein, high-energy diet as their normally grown preterm peers. However, because of the suspected immaturity of the urea cycle in these infants, high-protein intakes may lead to hyperammonemia. Ammonia is a known neurotoxin, and hyperammonemia is associated with lethargy, coma, and irreversible neuronal damage (13). Thus, neonatal treatment of the infant with IUGR may require a trade-off between keeping protein intake low enough to prevent ammonia intoxication but high enough to facilitate adequate growth. Relieving the hyperammonemia by stimulating the urea cycle therefore may be a possible strategy in the nutritional treatment of the neonate with IUGR.

Arginine is a high nitrogen-containing AA with several anabolic functions. It is part of the urea cycle and as such is a potent stimulator of urea production (14). Under normal conditions, arginine is not essential for protein metabolism, but in certain stressful situations, it may become essential (15). In traumatized or burned rats, as well as in patients who have undergone surgery, arginine supplementation has an anticatabolic effect and improves nitrogen balance (16-18). It is also known to enhance wound healing (19). Furthermore, arginine may be an essential nutrient for mother and fetus during pregnancy (20). Arginine stimulates secretion of insulin in human and ovine fetuses $(21,22)$ and also stimulates secretion of growth hormone (23) and glucagon (24). It therefore potentially could improve fetal growth and protein metabolism indirectly via these anabolic hormones. Arginine also serves as a precursor for polyamines involved in cell growth and DNA replication (25). The aims of our study, therefore, were to investigate the effect of IUGR on protein metabolism in the late-gestation ovine fetus and to determine the effects of arginine supplementation on protein metabolism in these animals.

\section{METHODS}

Animal preparation. Twenty-two pregnant Romney ewes that were carrying Dorset cross-breed singleton fetuses were housed in individual cages with free access to water and pelleted food. All experiments were approved by the University of Auckland Animal Ethics Committee.

The ewes underwent surgery under halothane anesthesia at $111 \pm 0.6$ gestation $($ term $=145 \mathrm{~d})$. Catheters were placed in both fetal femoral arteries and veins (FA and FV), the fetal common umbilical vein (UV), the main arteries that supply the maternal uterine horns (UA), the maternal utero-ovarian vein that drains the pregnant horn (UOV), and the maternal carotid artery (MA) and jugular vein (MV). Growth catheters were inserted s.c. around either side of the fetal chest and were attached to the spine and sternum (26). Fetal girth and hock-hoof length were measured. Ewes were allowed to recover for at least $3 \mathrm{~d}$ after surgery. All catheters were flushed with sterile saline that contained $10 \mathrm{U} / \mathrm{mL}$ heparin daily for the first $3 \mathrm{~d}$ postoperatively and subsequently every other day until post mortem. Fetal chest girth increments were measured twice daily.

Embolization. Animals were assigned at random to control and IUGR groups. In the IUGR group, placental embolization was begun at $114 \pm 0.9 \mathrm{~d}$ gestation. Microspheres (Superose 12; Pharmacia Biotech, Uppsala, Sweden; diluted $1: 100,1 \mathrm{~mL}$ per injection) were injected twice daily into the uterine arteries. Embolization was stopped $2 \mathrm{~d}$ before the first tracer study or if the fetal arterial $\mathrm{PO}_{2}$ was $<14 \mathrm{~mm} \mathrm{Hg}$, fetal blood lactate concentration was $>2$ $\mathrm{mM}$, or chest girth did not increase for 2 consecutive days.

Experimental protocol. Tracer infusion studies were performed on each animal at 120 (study 1) and 126 d gestation (study 2). In one of the studies, fetal protein metabolism was assessed before and after the infusion of arginine and in the other before and after infusion of an isonitrogenous solution of mixed AAs. The order of the studies was randomly determined for each animal.

After baseline blood samples were taken, $\mathrm{L}-\left[\operatorname{ring}{ }_{-}{ }^{2} \mathrm{H}_{5}\right]$ phenylalanine $\left(\mathrm{D}_{5}\right.$ phenylalanine, $0.8 \mu \mathrm{mol} / \mathrm{min}), \mathrm{L}-\left[\operatorname{ring}_{-}{ }^{2} \mathrm{H}_{2}\right]$ tyrosine $\left(\mathrm{D}_{2}\right.$-tyrosine, $0.15 \mu \mathrm{mol} /$ $\mathrm{min})$, and antipyrine $(0.4 \mathrm{mg} / \mathrm{min})$ were infused into the FV catheter, and $\mathrm{L}-\left[1-{ }^{13} \mathrm{C}\right]$ phenylalanine $\left({ }^{13} \mathrm{C}\right.$-phenylalanine, $\left.2.65 \mu \mathrm{mol} / \mathrm{min}\right)$ was infused into the MV catheter for $8 \mathrm{~h}$ (Fig. 1). All tracers were obtained from Cambridge Isotopes (ARC Laboratories, Amsterdam, The Netherlands). Priming doses equivalent to $100 \mathrm{~min}$ of infusate were given as a bolus at the start of infusion. An additional infusion of $0.9 \% \mathrm{NaCl}$ at $3 \mathrm{~mL} / \mathrm{h}$ was given via the $\mathrm{FV}$ catheter. Steady state was reached for all fetal tracers at $180 \mathrm{~min}$, after which five sets of blood samples were taken simultaneously from FA, FV, UV, MA, and UOV catheters at 15-min intervals. The FA and FV samples were taken from the hind limb that was not used for infusion, and care was taken to draw the sample slowly and gently to avoid drawing blood back from the vena cava that may contain the infusate from the other FV catheter. Immediately after the fifth set of samples, the saline infusion was changed to L-arginine $(12.2 \mu \mathrm{mol} / \mathrm{min})$ or a mixed AA solution (10\% FreAmine III; Braun Medical, Irvine, CA; $13.4 \mathrm{~mL}$ made up to $15 \mathrm{~mL}$ with saline, run at $3 \mathrm{~mL} / \mathrm{h}$; specific composition in Table 1 ). Both infusates contained $0.98 \mathrm{mM}$ nitrogen. A new steady state was reached after another $180 \mathrm{~min}$, after which an additional set of five blood samples were taken.

Whole blood was aliquotted into tubes in frozen gel blocks and stored at $-80^{\circ} \mathrm{C}$ until further analysis. An additional aliquot was kept on ice for measurement of blood gases on a Chiron M845 blood gas analyzer (Chiron Corp., Emeryville, CA) within $15 \mathrm{~min}$ of sampling. Additional aliquots were centrifuged, and the plasma was frozen at $-20^{\circ} \mathrm{C}$.

After study 1, the fetus was transfused with $20 \mathrm{~mL}$ of maternal blood immediately after the last sample was taken to replace blood lost in sampling. On the morning after study $2(127 \pm 1.0 \mathrm{~d}$ gestation), ewes were killed with an overdose of pentobarbitone. The fetus was removed, and all catheter positions were checked. The fetus was weighed and measured, and placentomes were dissected, weighed, and individually classified according to Vatnick et al. (27).

Assays. Antipyrine concentrations were analyzed in whole blood by HPLC (28). Plasma IGF-1 and insulin concentrations were measured by doubleantibody RIAs validated for sheep plasma $(29,30)$.

Isotopic enrichments of phenylalanine and tyrosine were analyzed in plasma by gas chromatography-mass spectrometry as described previously (31). In short, phenylalanine and tyrosine were converted to their methylformated pentafluorobenzyl derivatives, with addition of ${ }^{2} \mathrm{H}_{8}$-phenylalanine and ${ }^{13} \mathrm{C}_{9}$-tyrosine as internal standards. Quality control standards were derivatized in triplicate with each set of samples. Isotopic enrichments were measured on an HP Engine (Hewlett-Packard, Avondale, PA) that consisted of a 5890-series II gas chromatograph and a 5989B quadrupole mass spectrometer. The analytes were monitored for their [M-H]-ions at 190.2, 191.2, 195.2, and 198.2 $\mathrm{m} / \mathrm{z}$ for phenylalanine and at $264.2,266.2,268.2$, and $273.2 \mathrm{~m} / \mathrm{z}$ for tyrosine. Negative ion chemical ionization was used with ammonia as reaction gas at optimized pressure. Samples were injected using a heated split/splitless injec-

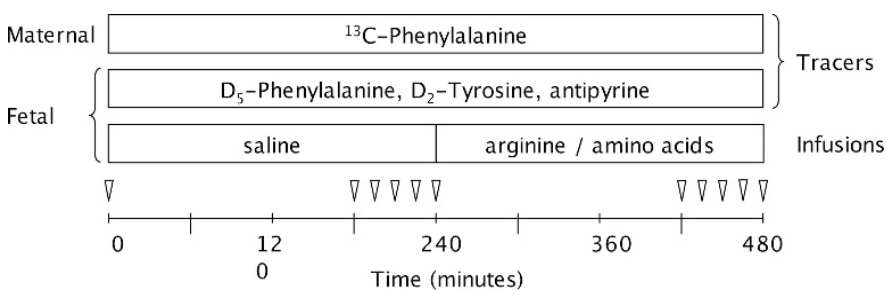

Figure 1. Experimental design of the protein metabolism studies. The arrows indicate times of blood sampling. Priming doses of all tracers were given at time 0 after baseline blood samples were taken. 
Table 1. Composition of the amino acid infusate

\begin{tabular}{lr}
\hline & $\mathrm{g} / \mathrm{L}$ \\
\hline Alanine & 6.34 \\
Arginine & 8.49 \\
Cysteine & $<0.14$ \\
Glycine & 12.51 \\
Histidine & 2.50 \\
Isoleucine & 6.16 \\
Leucine & 8.13 \\
Lysine & 6.52 \\
Methionine & 4.73 \\
Phenylalanine & 5.00 \\
Proline & 1.00 \\
Serine & 5.27 \\
Threonine & 3.57 \\
Tryptophan & 1.34 \\
Valine & 5.90
\end{tabular}

Values are those stated by the manufacturer (10\% FreAmine III, Braun Medical Inc., Irvine, USA) made to an $89.3 \%$ solution with sterile saline.

tor $(\mathrm{T}=270 \mathrm{C})$. A CP-Sil-19CB $25 \mathrm{~m} \times 0.25 \mathrm{~mm}($ I.D. $) \times 0.2 \mu \mathrm{m}($ film thickness) column (Chrompak International, Middelburg, The Netherlands) was used with helium as carrier gas. Inter- and intra-assay variabilities were $<8$ and $<4 \%$, respectively, for each isotope.

Calculations. Umbilical and uterine blood flows $(\mathrm{ml} / \mathrm{min})$ were calculated from antipyrine concentrations according to the Fick principle, as the quotient of the infusion rate and the arteriovenous concentration difference across the placenta (32):

Umbilical blood flow $=\mathrm{I} /[\Delta \text { antipyrine }]_{\mathrm{FA}-\mathrm{UV}}$

Uterine blood flow $=\mathrm{I} /[\Delta \text { antipyrine }]_{\text {UOV-MA }}$

where $\mathrm{I}$ is the antipyrine infusion rate in $\mu \mathrm{g} / \mathrm{min}$, and the blood antipyrine concentrations are in $\mu \mathrm{g} / \mathrm{mL}$.

Hind limb blood flow (HIBF) was assumed to be a constant fraction of umbilical blood flow, based on a previous study in late-gestation sheep in which hind limb and umbilical blood flows were determined using radiolabeled microspheres (33). Blood flows were converted to plasma flows as follows:

$\mathrm{PF}=\mathrm{BF} *(1-$ fractional hematocrit $)$

Whole-body phenylalanine kinetics. Whole-body phenylalanine kinetics were estimated by the method of Clarke and Bier (34), adapted for the ovine fetus by Liechty et al. (35). Turnovers $(\mathrm{Q} ; \mu \mathrm{mol} / \mathrm{min})$ of phenylalanine and tyrosine were estimated from the plasma dilution of the infused tracers with the following equation:

$\mathrm{Q}=\mathrm{I} *[(\mathrm{Ri} / \mathrm{Rp})-1]$

where $\mathrm{I}$ is the tracer infusion rate $(\mu \mathrm{mol} / \mathrm{min})$ and $\mathrm{Ri}$ and $\mathrm{Rp}$ are the tracer/tracee ratios (TTR) in the infusate and plasma, respectively.

Phenylalanine hydroxylation to tyrosine $(\mathrm{OH}, \mu \mathrm{mol} / \mathrm{min})$ was calculated as follows:

$\mathrm{OH}=\mathrm{Q}_{\mathrm{D} 2 \text {-tyr }} *\left(\mathrm{R}_{\mathrm{D} 4-\mathrm{tyr}} / \mathrm{R}_{\mathrm{phe}}\right) *\left[\mathrm{Q}_{\mathrm{phe}} /\left(\mathrm{I}_{\mathrm{phe}}+\mathrm{Q}_{\mathrm{phe}}\right)\right]$

where $\mathrm{Q}_{\mathrm{D} 2 \text {-tyr }}$ is the turnover of tyrosine, derived from plasma enrichments of $\mathrm{D}_{2}$-tyrosine; $\mathrm{Q}_{\text {phe }}$ is the turnover of phenylalanine; $\mathrm{I}_{\text {phe }}$ is infusion rate of $\mathrm{D}_{5}$-phenylalanine; $\mathrm{R}_{\mathrm{D} 4 \text {-tyr }}$ is the TTR of $\mathrm{D}_{4}$-tyrosine in plasma, which is derived from hydroxylation of the $\mathrm{D}_{5}$-phenylalanine tracer; and $\mathrm{R}_{\mathrm{phe}}$ is the TTR of $\mathrm{D}_{5}$-phenylalanine in plasma.

The influx of maternal phenylalanine to the fetal circulation $\left(Q_{m} \rightarrow f\right.$; $\mu \mathrm{mol} / \mathrm{min}$ ) was estimated by dilution of the maternal tracer in fetal plasma:

$\mathrm{Q}_{\mathrm{m}} \rightarrow \mathrm{f}=\left[\left(\mathrm{R}_{\mathrm{f}}^{\mathrm{m}} * \mathrm{Q}_{\mathrm{f}}\right) / \mathrm{I}_{\mathrm{m}}\right] * \mathrm{Q}_{\mathrm{m}}$

where $\mathrm{R}^{\mathrm{m}}{ }_{\mathrm{f}}$ is the TTR of the maternal tracer $\left({ }^{13} \mathrm{C}\right.$-phenylalanine) in the fetal plasma, $I_{m}$ is the infusion rate of the maternal tracer, $Q_{f}$ is the turnover of phenylalanine in the fetal plasma, and $\mathrm{Q}_{\mathrm{m}}$ is the turnover of phenylalanine in maternal plasma. This estimate assumes that there is no utilization of maternally derived phenylalanine by the placenta. Therefore, it will overestimate $\mathrm{Q}_{\mathrm{m}} \rightarrow \mathrm{f}$ to the extent that maternal tracer is used by the placenta (35).

The unidirectional flux of phenylalanine from the fetal plasma to the placenta $\left(\mathrm{Q}_{\mathrm{f}} \rightarrow \mathrm{m} ; \mu \mathrm{mol} / \mathrm{min}\right)$ was estimated by the Fick principle as the product of the umbilical plasma flow and the loss of tracer across the placenta:

$\mathrm{Q}_{\mathrm{f}} \rightarrow \mathrm{m}=\mathrm{UmPF} *\left[\left(\mathrm{R}_{\mathrm{FA}} *[\mathrm{FA}]\right)-\left(\mathrm{R}_{\mathrm{UV}} *[\mathrm{UV}]\right)\right]$

where $R_{F A}$ and $R_{U V}$ are the TTRs of D5-phenylalanine, and [FA] and [UV] are the concentrations of phenylalanine in FA and UV plasma, respectively $(\mu \mathrm{mol} / \mathrm{mL})$.

Because phenylalanine cannot be newly synthesized in the body, release of phenylalanine from body protein breakdown $(\mathrm{B} ; \mu \mathrm{mol} / \mathrm{min})$ is the difference between the total phenylalanine turnover and phenylalanine derived from the mother and tracer and AA infusions:
$\mathrm{B}=\mathrm{Q}-\left(\mathrm{I}+\mathrm{Q}_{\mathrm{m}} \rightarrow \mathrm{f}\right)$

where $\mathrm{I}$ is the combined infusion rate of phenylalanine as tracer and in the AA mixture $(\mu \mathrm{mol} / \mathrm{min})$.

Phenylalanine used for protein synthesis $(\mathrm{S} ; \mu \mathrm{mol} / \mathrm{min})$ is the difference between the turnover and the disappearance of phenylalanine toward the mother and to tyrosine:

$\mathrm{S}=\mathrm{Q}-\left(\mathrm{OH}+\mathrm{Q}_{\mathrm{f}} \rightarrow \mathrm{m}\right)$

Phenylalanine used for protein accretion is the net balance between synthesis and breakdown.

Hind Limb Phenylalanine kinetics. Phenylalanine kinetics across the hind limb were calculated as described by Wolfe (36). The net tracer balance (NB) across the hind limb (nmol/min) is a measure for hind limb protein accretion and is calculated as shown below:

$\mathrm{NB}=\mathrm{HIPF} *\left[\left([\mathrm{FA}] * \mathrm{R}_{\mathrm{FA}}\right)-\left([\mathrm{FV}] * \mathrm{R}_{\mathrm{FV}}\right)\right]$

where HIPF is the plasma flow across the hind limb ( $\mathrm{ml} / \mathrm{min}),[\mathrm{FA}]$ and $[\mathrm{FV}]$ are the phenylalanine concentrations in FA and FV plasma, respectively $\left(\mathrm{nmol} / \mathrm{mL}\right.$ ), and $\mathrm{R}_{\mathrm{FA}}$ and $\mathrm{R}_{\mathrm{FV}}$ are the TTRs in FA and FV plasma.

As there is relatively low phenylalanine 4-monooxygenase activity (37) and, therefore, phenylalanine hydroxylation, in muscle, the hind-limb disposal rate of phenylalanine $(\mathrm{Rd} ; \mathrm{nmol} / \mathrm{min})$ is a reflection of protein synthesis. This was calculated as follows:

$\mathrm{Rd}=\mathrm{NB} / \mathrm{R}_{\mathrm{FV}}$

The $\mathrm{R}_{\mathrm{FV}}$ is thought to best represent the intracellular enrichment of the organ (38).

The production rate $(\mathrm{Ra} ; \mathrm{nmol} / \mathrm{min})$ of phenylalanine in muscle represents the rate of protein breakdown. The NB of an AA across an organ is the net difference between production and disposal; therefore, the hind limb phenylalanine production rate is represented as:

$\mathrm{Ra}=\mathrm{Rd}-\mathrm{NB}$

Statistics. The results are presented as mean \pm SD. For each animal, the means of the five measurements during saline infusion and the five during arginine or AA infusion were calculated. Baseline differences between control and embolized groups were analyzed using $t$ test for unpaired measurements. The effects of arginine or AA infusion were analyzed using repeated measures ANOVA taking into account infusion (before versus after), group (embolized versus control), and infusion $\times$ group interaction. Because of the relatively small sample size, baseline differences between the two groups in hind limb protein kinetics were analyzed with Mann-Whitney tests. Differences within groups in hind limb protein kinetics were analyzed with Wilcoxon signed rank tests. The results of these are expressed as median (range). There were no significant differences between the two study days in baseline values of any of the major outcomes; therefore, the results for both days were pooled for statistical analysis.

\section{RESULTS}

The gestational ages at the two protein turnover studies were the same in both groups $(120.3 \pm 0.5$ and $126.1 \pm 1.1 \mathrm{~d}$ in the control animals and at $120.5 \pm 0.5$ and $126.4 \pm 0.5 \mathrm{~d}$ in the embolized group). The gestational ages at post mortem were also similar in the two groups (control $127.1 \pm 1.1 \mathrm{~d}$; embolized $127.0 \pm 0.9 \mathrm{~d}$ ).

Embolization did not significantly reduce fetal weight at post mortem (Table 2). However, the fetal growth rate was reduced in the embolized group, as indicated by a decrease in the daily increment in hock-hoof length and chest girth between surgery and post mortem. Placental weight was also reduced by $17 \%$ in the embolized group, although this did not reach statistical significance $(p=0.06)$. The distribution of placentomes was shifted toward the more mature stage in the embolized group, with lower median weight of total type-A placentomes [median (range): control 329 (152-489) g versus embolized 194 (20379) $\mathrm{g} ; p=0.03$ ] and higher median weight of total type $\mathrm{C}$ placentomes [control $30(15-46)$ g versus embolized 123 $(15-216) \mathrm{g} ; p=0.05]$. 
Table 2. Effect of embolization on fetal and placental size, and on blood gases, plasma hormone and metabolite concentrations and plasma flows at baseline

\begin{tabular}{|c|c|c|c|c|}
\hline & Control & $n$ & Embolized & $n$ \\
\hline \multicolumn{5}{|l|}{ Measurements } \\
\hline Fetal weight $(\mathrm{g})$ & $3585 \pm 456$ & (10) & $3347 \pm 668$ & (11) \\
\hline Hock-hoof increment $(\mathrm{mm} / \mathrm{d})$ & $2.6 \pm 0.5$ & (10) & $2.1 \pm 0.4 *$ & (10) \\
\hline Placental weight (g) & $432 \pm 83$ & (10) & $358 \pm 73$ & (10) \\
\hline \multicolumn{5}{|l|}{ Fetal arterial blood gases } \\
\hline $\mathrm{pO}_{2}(\mathrm{mmHg})$ & $19 \pm 3$ & (20) & $16 \pm 3 \dagger$ & (19) \\
\hline $\mathrm{pH}$ & $7.35 \pm 0.02$ & (20) & $7.35 \pm 0.04$ & (19) \\
\hline \multicolumn{5}{|l|}{ Plasma hormones (ng/ml) } \\
\hline Fetal IGF-1 & $68 \pm 20$ & (19) & $51 \pm 19^{*}$ & (18) \\
\hline Maternal IGF-1 & $115 \pm 27$ & (19) & $133 \pm 28 *$ & (19) \\
\hline Fetal insulin & $0.24 \pm 0.16$ & (16) & $0.17 \pm 0.16$ & (17) \\
\hline Maternal insulin & $0.29 \pm 0.10$ & (14) & $0.51 \pm 0.33 *$ & (17) \\
\hline Maternal lactate & $0.72 \pm 0.15$ & (18) & $0.77 \pm 0.28$ & (19) \\
\hline \multicolumn{5}{|l|}{ Plasma flows (ml/min) } \\
\hline Uterine plasma flow & $1070 \pm 195$ & (13) & $758 \pm 250 \ddagger$ & (15) \\
\hline Umbilical plasma flow & $370 \pm 102$ & (18) & $386 \pm 111$ & (18) \\
\hline
\end{tabular}

Values are mean $\pm \mathrm{SD}(n)$. Values for blood gases, hormone and metabolite concentrations and plasma flows are the baseline results on both study days. $* p=0.05 ; \dagger p=0.01 ; \ddagger p=0.001$ for comparison with control animals.

\section{Blood Gases, Plasma Hormone and Metabolite Concentrations, and Plasma Flows}

Effects of embolization. Placental embolization significantly reduced fetal arterial $\mathrm{Po}_{2}$ and increased fetal hematocrit but did not result in hypercapnia or acidemia at the time of study (Table 2). Embolization reduced fetal and increased maternal IGF-1 concentrations. Fetal insulin concentrations were not different between embolized and control groups, but maternal concentrations were elevated in the embolized group. There were no differences in baseline fetal and maternal glucose or lactate concentrations between the two groups. Embolization reduced baseline uterine plasma flow by $\sim 30 \%$, but umbilical plasma flow was not changed (Table 2).

Effects of mixed AA or arginine supplementation. Fetal IGF-1 concentrations were not altered by either AA or arginine infusion in either group (AA infusion: controls $70 \pm 20$ to 66 $\pm 22 \mathrm{ng} / \mathrm{mL}$, embolized $65 \pm 11$ to $60 \pm 10 \mathrm{ng} / \mathrm{mL}$; arginine infusion: controls $66 \pm 21$ to $64 \pm 21 \mathrm{ng} / \mathrm{mL}$, embolized $49 \pm$ 24 to $51 \pm 25 \mathrm{ng} / \mathrm{mL}$ ). AA infusion increased fetal insulin concentrations in both groups (controls $0.30 \pm 0.22$ to $0.37 \pm$ $0.23 \mathrm{ng} / \mathrm{mL}$, embolized $0.21 \pm 0.21$ to $0.42 \pm 0.52 \mathrm{ng} / \mathrm{mL}$; infusion effect $p \leq 0.05$, group $\times$ infusion interaction $p=0.3$ ). Arginine infusion also increased fetal plasma insulin concentrations to a similar extent in both groups (control $0.20 \pm 0.09$ to $0.29 \pm 0.10 \mathrm{ng} / \mathrm{mL}$, embolized $0.13 \pm 0.14$ to $0.22 \pm 0.20$ $\mathrm{ng} / \mathrm{mL}$; infusion effect $p \leq 0.001$, group $\times$ infusion interaction $p=1.0$ ). Maternal hormone concentrations were not changed by either AA or arginine infusion (data not shown).

AA infusion did not change uterine or umbilical plasma flows in either group (data not shown). Umbilical plasma flows were reduced by arginine infusion to a similar extent in both groups (controls $374 \pm 83$ to $334 \pm 72.6 \mathrm{~mL} / \mathrm{min}$, embolized
$380 \pm 106$ to $344 \pm 130 \mathrm{~mL} / \mathrm{min} ; p \leq 0.01$, group $\times$ infusion interaction $p=0.5$ ). Uterine plasma flows were not changed by arginine infusion in either group.

\section{Phenylalanine Kinetics}

Arginine concentrations before arginine or AA infusion were lower in the embolized animals when results from all studies were pooled (controls $108 \pm 30 \mu \mathrm{M}$, embolized $85 \pm$ $31 \mu \mathrm{M} ; p \leq 0.05$ ) but not when separated for AA or arginine infusion studies (Table 3 ). There were no differences in phenylalanine or tyrosine concentrations between control and embolized animals. Mixed AA infusion increased fetal plasma phenylalanine and tyrosine concentrations in both control and embolized animals. Arginine infusion approximately doubled fetal plasma arginine concentrations in both groups (Table 3).

There were no differences in any of the phenylalanine or tyrosine kinetic data between control and embolized animals (Fig. 2). The effects of AA infusion were also not different between control and embolized animals. AA infusion increased whole-body phenylalanine turnover and phenylalanine hydroxylation rates (Fig. 2A). Tyrosine turnover did not change. Phenylalanine used for protein synthesis was increased, whereas phenylalanine released from protein breakdown was reduced. The net effect of mixed AA infusion in both groups was an increase in protein accretion.

The effects of arginine infusion were not different between the control and embolized animals. Arginine infusion decreased whole-body phenylalanine and tyrosine turnovers (Fig. $2 B$ ). Phenylalanine hydroxylation rates were not affected by arginine infusion. Arginine infusion reduced protein synthesis and breakdown, resulting in a net increase in protein accretion. 
Table 3. Effects of mixed amino acid or arginine infusion on plasma amino acid concentrations

\begin{tabular}{|c|c|c|c|c|}
\hline & \multicolumn{2}{|c|}{ Controls } & \multicolumn{2}{|c|}{ Embolized } \\
\hline \multicolumn{5}{|c|}{ Amino acid infusion } \\
\hline Tyrosine & $106 \pm 21$ & $116 \pm 24$ & $106 \pm 24$ & $117 \pm 19 \ddagger$ \\
\hline Arginine & $109 \pm 18$ & $131 \pm 21$ & $94 \pm 26$ & $117 \pm 45 \ddagger$ \\
\hline \multicolumn{5}{|l|}{ Arginine infusion } \\
\hline Arginine & $108 \pm 36$ & $198 \pm 74$ & $87 \pm 40$ & $182 \pm 60 \S$ \\
\hline
\end{tabular}

Values are mean $\pm \mathrm{SD}$ in $\mu \mathrm{mol} / \mathrm{L}$ for nine control and nine embolized animals receiving amino acid infusion and 10 control and 10 embolized animals receiving arginine infusion.

$* p=0.05 ; \ddagger p=0.001 ; \S p=0.0001$ for infusion effect. There were no significant group effects or group $\mathrm{x}$ infusion interactions.

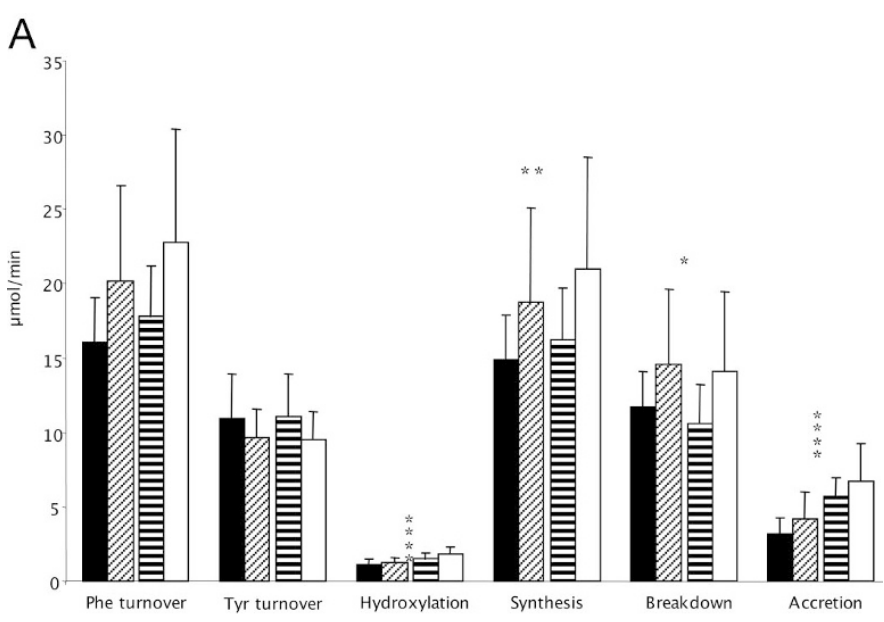

B

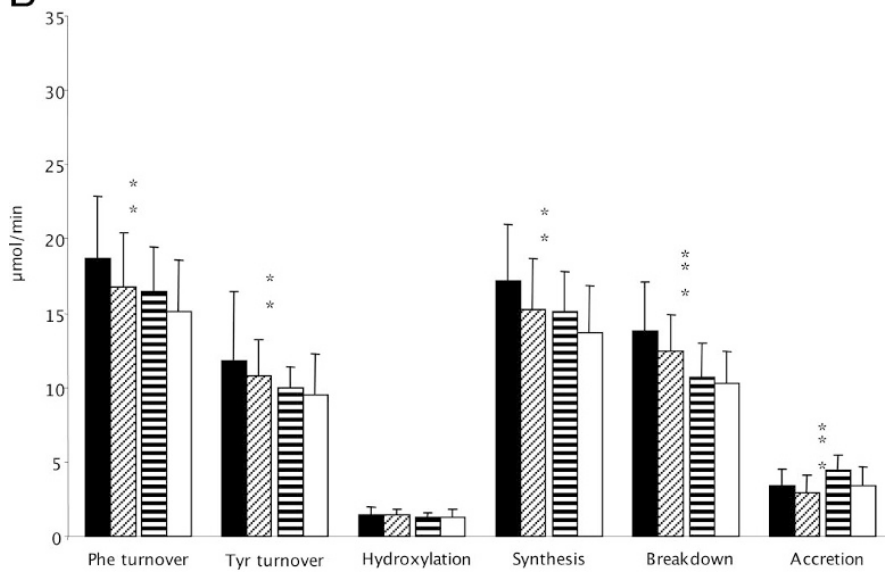

Figure 2. The effects of AA $(A)$ and arginine infusion $(B)$ on phenylalanine and tyrosine kinetics. Values are mean \pm SD for nine control and eight embolized animals after AA infusion and 10 control and 10 embolized animals after arginine infusion. Synthesis, breakdown, and accretion indicate the amount of phenylalanine used for whole-body protein synthesis, breakdown, and accretion. $* p \leq 0.05, * * p \leq 0.01, * * * p \leq 0.001, * * * * p \leq 0.0001$ for infusion effect (before $v s$ after, repeated measures ANOVA). There were no significant group effects or group $\times$ infusion interactions. Controls before infusion; 目 Controls after infusion; $\mathbb{Z}$ Embolized before infusion; $\square$ Embolised after infusion.

Hind limb phenylalanine synthesis, breakdown, and accretion rates were not different between control and embolized animals (Table 4). Hind limb protein kinetics did not change in response to AA or arginine infusion.
When expressed as change from baseline values, AA and arginine supplementations had significantly different effects on protein turnover and synthesis in both groups (Table 5). AAs increased, whereas arginine reduced protein synthesis and turnover. The effects of treatments on protein breakdown were not different from each other. AA supplementation increased protein accretion more than arginine supplementation. Arginine and AA supplementation had similar effects on hind limb protein kinetics.

\section{DISCUSSION}

This study was undertaken to determine the effects of IUGR on protein metabolism in the ovine fetus and the effects of arginine or mixed AA infusion on protein metabolism in these animals. Our study showed no effect of placental embolization on any of the measured parameters of protein metabolism. This might be because the growth restriction in our animals was relatively mild. Fetal weight at post mortem was not significantly reduced in the embolized group, as a result of the large biologic variance. However, embolized fetuses did have significantly reduced growth as measured by chest girth increment and hind limb growth, measurements with much smaller variance in this study. In addition, embolized animals had reduced placental weight, uterine plasma flow, fetal $\mathrm{Po}_{2}$, and fetal IGF-1 concentrations. Nevertheless, our failure to detect significant changes in protein metabolism in these fetuses with mild growth restriction does not exclude the possibility that altered protein metabolism may be demonstrable after more severe or prolonged IUGR.

We found that arginine and mixed AA infusions both increased fetal protein accretion but did so by distinctly different mechanisms. Whereas mixed AA infusion increased protein turnover and synthesis and reduced protein breakdown, arginine infusion decreased turnover, synthesis, and breakdown. The increase in protein synthesis after AA infusion was to be expected as AAs are the prime substrate for protein synthesis. AAs are also known to have an inhibitory effect on protein breakdown (39), which is at least partly caused by reduction of proteasome activity (40).

The inhibitory effect of arginine on whole-body protein turnover has been observed before in a study of sepsis in pigs (41). This study showed that the decrease in whole-body protein turnover was most likely to be caused by a reduction in 
Table 4. Effects of mixed amino acid or arginine infusion on hind limb phenylalanine kinetics

\begin{tabular}{|c|c|c|c|c|}
\hline & \multicolumn{2}{|c|}{ Control } & \multicolumn{2}{|c|}{ Embolized } \\
\hline \multicolumn{5}{|c|}{ Amino acid infusion } \\
\hline Breakdown & $642(353-1525)$ & $713(330-1783)$ & $615(267-916)$ & $484(431-1101)$ \\
\hline Accretion & $31(18-77)$ & $29(16-82)$ & $27(13-44)$ & $25(16-45)$ \\
\hline \multicolumn{5}{|c|}{ Arginine infusion } \\
\hline Accretion & $24(20-40)$ & $34(15-42)$ & $26(23-34)$ & $28(27-36)$ \\
\hline
\end{tabular}

Values are median (range) for six control and four embolized animals receiving amino acid infusion and three control and three embolized animals receiving arginine infusion. Synthesis, breakdown and accretion values represent the amount of phenylalanine used for protein synthesis, breakdown and accretion. There were no significant effects of group or infusion.

Table 5. Changes from baseline in phenylalanine/tyrosine kinetics after mixed amino acid or arginine infusion

\begin{tabular}{|c|c|c|c|c|}
\hline & \multicolumn{2}{|c|}{ Control } & \multicolumn{2}{|c|}{ Embolized } \\
\hline & Amino acids & Arginine & Amino acids & Arginine \\
\hline \multicolumn{5}{|c|}{ Whole-body kinetics $(\mu \mathrm{mol} / \mathrm{min})$} \\
\hline${ }^{\mathrm{F}} \mathrm{Q}_{\mathrm{Tyr}}$ & $0.4 \pm 1.2$ & $-2.7 \pm 4.4$ & $-0.1 \pm 0.7$ & $-0.9 \pm 1.3$ \\
\hline Hydroxylation & $0.5 \pm 0.3$ & $-0.2 \pm 0.5$ & $0.5 \pm 0.3$ & $-0.1 \pm 0.2 \ddagger$ \\
\hline Synthesis & $1.3 \pm 2.0$ & $-2.4 \pm 3.2$ & $2.2 \pm 2.2$ & $-1.4 \pm 1.4 \dagger$ \\
\hline \multicolumn{5}{|c|}{ Hind limb kinetics (nmol/min) } \\
\hline Synthesis & $\begin{array}{c}-31 \\
(-134-264)\end{array}$ & $\begin{array}{c}-83 \\
(-122-205)\end{array}$ & $\begin{array}{c}32 \\
(-161-186)\end{array}$ & $\begin{array}{c}0 \\
(-3-140)\end{array}$ \\
\hline Breakdown & $\begin{array}{c}-27 \\
(-130-258)\end{array}$ & $\begin{array}{c}-85 \\
(-117-195)\end{array}$ & $\begin{array}{c}28 \\
(155-185)\end{array}$ & $\begin{array}{c}-2 \\
(-3-135)\end{array}$ \\
\hline Accretion & $\begin{array}{c}-2 \\
(-5-6)\end{array}$ & $\begin{array}{c}2 \\
(-4-10)\end{array}$ & $\begin{array}{c}-1.5 \\
(-7-12)\end{array}$ & $\begin{array}{c}2 \\
(0-5)\end{array}$ \\
\hline
\end{tabular}

Values are mean $\pm \mathrm{SD}$ in $\mu \mathrm{mol} / \mathrm{min}$ for eight control and seven embolized animals for whole-body kinetics and median (range) in nmol/min for three control and three embolized animals for hind limb kinetics. There were no significant group effects or group x infusion interactions.

${ }^{\mathrm{F}} \mathrm{Q}_{\mathrm{Phe}}$ and ${ }^{\mathrm{F}} \mathrm{Q}_{\mathrm{Tyr}}$ are whole-body phenylalanine and tyrosine turnover, respectively.

$\dagger p \leq 0.01 ; \ddagger p \leq 0.001 ; \S p \leq 0.0001$ for comparison between effects of amino acid and arginine infusion.

liver protein synthesis and breakdown, despite an increase in hindquarter protein turnover. In our study, there was no change in hind limb protein metabolism in response to arginine infusion, and the cause of the decrease in whole-body protein turnover therefore must be located elsewhere. The liver may be a possible candidate. The biologic meaning of the inhibitory effect of arginine on whole-body protein turnover is as yet unexplained.

Arginine suppressed protein synthesis despite increased insulin concentrations, which would be expected to stimulate protein synthesis (42). A possible explanation may lie in the organ-specific actions of arginine. Skeletal muscle is the main site of insulin action (43). Although our study failed to show a change in hind limb protein metabolism after arginine infusion, previous studies in other animal models have shown an increase in muscle protein turnover and synthesis $(17,41)$. Thus, arginine infusion may have an insulin-dependent action on protein metabolism in skeletal muscle while affecting other organs in different ways.

There are several possible reasons why our study failed to show an effect of arginine infusion on hind limb protein metabolism. First, the animals in the other studies were in a state of catabolism at the start of arginine supplementation, whereas our animals were not. Increased protein turnover is thought to facilitate rapid elimination of damaged proteins (41). This may be an essential healing strategy during trauma such as burn injury or sepsis. Second, we studied the lambs in utero, whereas the other studies were done in adult or adolescent animals. Thus, the effects of arginine infusion on protein metabolism may be different in the rapidly growing and maturing organism. Finally, because of practical problems with sampling of the venous catheters, the number of measurements of hind limb metabolism is small in our study and the variance is large. It therefore is possible that the statistical power of our study was not large enough to detect anything but large differences in hind limb protein kinetics after arginine infusion.

Mixed AA infusion had a greater effect on protein accretion rates than arginine infusion and therefore seems to be a potentially better strategy for improving fetal growth. Charlton and Johengen $(44,45)$ showed previously that both fetal intragastric and i.v. mixed AA and glucose supplementation prevented growth restriction in the ovine fetus induced by undernutrition or embolization, but they did not study fetal protein metabolism. We have shown that stimulating protein accretion may be one of the underlying mechanisms for this effect.

Arginine supplementation reduced umbilical plasma flows in both control and embolized groups, although this was not statistically significant in the embolized group. In many cell 
types, arginine is a precursor for the production of nitric oxide (NO), a vasodilator (46,47). The increased arginine levels in our study may have led to increased fetal peripheral vasodilation by means of increased NO production, redistributing the blood flow away from the placenta toward the fetus. This would give rise to systematic errors in our estimation of hind limb protein metabolism, as in the absence of direct measures of $\mathrm{HlBF}$, we were forced to assume that it remained a fixed percentage of the umbilical blood flow. This assumption would not have been valid if the observed fall in umbilical blood flow were accompanied by no change or even an increase in HIBF.

The only aspect of protein metabolism that we measured that is dependent on umbilical plasma flow is the phenylalanine flux from the fetal circulation back across the placenta. Although umbilical plasma flows were reduced after arginine infusion, this had no measurable effect on the fetal to maternal phenylalanine flux. Furthermore, if arginine led to increased fetal peripheral vasodilation, then it would be expected to lead to increased nutrient supply to fetal tissues, at least in the short term, and consequently to higher fetal protein turnover rates. However, arginine infusion decreased rather than increased fetal protein turnover in this study. Thus, it seems unlikely that arginine-induced increase in NO production has confounded our measurements of protein kinetics.

\section{CONCLUSION}

In conclusion, this study showed no effect of mild growth restriction on protein metabolism in the ovine fetus. Intravenous infusion of arginine or mixed AAs to the fetus increased protein accretion rates in both embolized and control fetuses. However, AA infusion increased protein turnover and synthesis rates, whereas arginine inhibited whole-body protein metabolism. AA infusion was more effective in stimulating protein accretion and therefore may be a better possible strategy for improving growth in utero. The biologic significance of the inhibitory effect of arginine on protein metabolism requires further investigation.

Acknowledgments. We gratefully acknowledge Toni SmithWong for technical assistance with the animal studies and Andrzej Surus for the insulin and IGF-1 assays. Drs. Frank Bloomfield and Mark Oliver helped review the manuscript.

\section{REFERENCES}

1. Bernstein IM, Horbar JD, Badger GJ, Ohlsson A, Golan A 2000 Morbidity and mortality among very-low-birth-weight neonates with intrauterine growth restriction. The Vermont Oxford Network. Am J Obstet Gynecol 182:198-206

2. Lee MJ, Conner EL, Charafeddine L, Woods JR Jr, Priore GD 2001 A critical birth weight and other determinants of survival for infants with severe intrauterine growth restriction. Ann N Y Acad Sci 943:326-339

3. Cauderay M, Schutz Y, Micheli JL, Calame A, Jequier E 1988 Energy-nitrogen balances and protein turnover in small and appropriate for gestational age low birthweight infants. Eur J Clin Nutr 42:125-136

4. Van Goudoever JB, Sulkers EJ, Halliday D, Degenhart HJ, Carnielli VP, Wattimena JL, Sauer PJ 1995 Whole-body protein turnover in preterm appropriate for gestational age and small for gestational age infants: comparison of $[15 \mathrm{~N}]$ glycine and [1-(13)C]leucine administered simultaneously. Pediatr Res 37:381-388

5. Pencharz PB, Masson M, Desgranges F, Papageorgiou A 1981 Total-body protein turnover in human premature neonates: effects of birth weight, intra-uterine nutritional status and diet. Clin Sci (Lond) 61:207-215
6. Ross JC, Fennessey PV, Wilkening RB, Battaglia FC, Meschia G 1996 Placental transport and fetal utilization of leucine in a model of fetal growth retardation. Am J Physiol 270:E491-E503

7. Cetin I, Corbetta C, Sereni LP, Marconi AM, Bozzetti P, Pardi G, Battaglia FC 1990 Umbilical amino acid concentrations in normal and growth-retarded fetuses sampled in utero by cordocentesis. Am J Obstet Gynecol 162:253-261

8. Cetin I, Ronzoni S, Marconi AM, Perugino G, Corbetta C, Battaglia FC, Pardi G 1996 Maternal concentrations and fetal-maternal concentration differences of plasma amino acids in normal and intrauterine growth-restricted pregnancies. Am J Obstet Gynecol 174:1575-1583

9. Cetin I, Marconi AM, Bozzetti P, Sereni LP, Corbetta C, Pardi G, Battaglia FC 1988 Umbilical amino acid concentrations in appropriate and small for gestational age infants: a biochemical difference present in utero. Am J Obstet Gynecol 158:120-126

10. Boehm G, Gedlu E, Muller DM, Beyreiss K, Raiha NC 1990 Relationship between urea and ammonium excretion in the urine of very-low-birth-weight infants appropriate for gestational age. Biomed Biochim Acta 49:69-74

11. Lafeber HN, Jones CT, Rolph TP 1979 Some of the consequences of intrauterine growth retardation. In: Visser HK (ed) Nutrition and Metabolism of the Fetus and Infant. Martinus Nijhof Publishers, The Hague, pp 43-63

12. Boehm G, Senger H, Muller D, Beyreiss K, Raiha NC 1988 Metabolic differences between AGA- and SGA-infants of very low birthweight. II. Relationship to protein intake. Acta Paediatr Scand 77:642-646

13. Msall M, Batshaw ML, Suss R, Brusilow SW, Mellits ED 1984 Neurologic outcome in children with inborn errors of urea synthesis. Outcome of urea-cycle enzymopathies. N Engl J Med 310:1500-1505

14. Leonard JV 2001 The nutritional management of urea cycle disorders. J Pediatr 138:S40-S44

15. Visek WJ 1985 Arginine and disease states. J Nutr 115:532-541

16. Daly JM, Reynolds J, Thom A, Kinsley L, Dietrick-Gallagher M, Shou J, Ruggieri B 1988 Immune and metabolic effects of arginine in the surgical patient. Ann Surg 208:512-523

17. Cui XL, Iwasa M, Iwasa Y, Ohmori Y, Yamamoto A, Maeda H, Kume M, Ogoshi S, Yokoyama A, Sugawara T, Funada T 1999 Effects of dietary arginine supplementation on protein turnover and tissue protein synthesis in scald-burn rats. Nutrition 15:563-569

18. Chyun JH, Griminger P 1984 Improvement of nitrogen retention by arginine and glycine supplementation and its relation to collagen synthesis in traumatized mature and aged rats. J Nutr 114:1697-1704

19. Barbul A, Lazarou SA, Efron DT, Wasserkrug HL, Efron G 1990 Arginine enhances wound healing and lymphocyte immune responses in humans. Surgery 108:331-336

20. Wu G, Meininger CJ, Knabe DA, Bazer FW, Rhoads JM 2000 Arginine nutrition in development, health and disease. Curr Opin Clin Nutr Metab Care 3:59-66

21. Milner RD, Ashworth MA, Barson AJ 1972 Insulin release from human foetal pancreas in response to glucose, leucine and arginine. J Endocrinol 52:497-505

22. Fowden AL 1980 Effects of arginine and glucose on the release of insulin in the sheep fetus. J Endocrinol 85:121-129

23. Merimee TJ, Rabinowitz D, Riggs L, Burgess JA, Rimoin DL, McKusick VA 1967 Plasma growth hormone after arginine infusion. Clinical experiences. N Engl J Med 276:434-439

24. Palmer JP, Walter RM, Ensinck JW 1975 Arginine-stimulated acute phase of insulin and glucagon secretion. I. In normal man. Diabetes 24:735-740

25. Hosomi M, Stace NH, Lirussi F, Smith SM, Murphy GM, Dowling RH 1987 Role of polyamines in intestinal adaptation in the rat. Eur J Clin Invest 17:375-385

26. Harding JE 1997 Prior growth rate determines the fetal growth response to acute maternal undernutrition in fetal sheep of late gestation. Prenat Neonatal Med 2:300309

27. Vatnick I, Schoknecht PA, Darrigrand R, Bell AW 1991 Growth and metabolism of the placenta after unilateral fetectomy in twin pregnant ewes. J Dev Physiol 15:351356

28. Pimentel G, Figueroa JP, Mitchell MD, Massmann A, Nathanielsz PW 1986 Effect of fetal and maternal intravascular antipyrine infusion on maternal plasma prostaglandin concentrations in the pregnant sheep at 104 to 127 days' gestation. Am J Obstet Gynecol 155:1181-1185

29. Blum WF, Breier BH 1994 Radioimmunoassays for IGFs and IGFBPs. Growth Regul 4:11-19

30. Oliver MH, Harding JE, Breier BH, Evans PC, Gluckman PD 1993 Glucose but not a mixed amino acid infusion regulates plasma insulin-like growth factor-I concentrations in fetal sheep. Pediatr Res 34:62-65

31. Kulik W, van Toledo-Eppinga L, Kok RM, Guérand WS, Lafeber HN 1995 Simultaneous determination of concentrations and stable isotope enrichments of $\alpha$-ketoisocaproic acid, leucine, phenylalanine and tyrosine in blood plasma by gas chromatography/negative ion mass spectrometry. J Mass Spectrom 30:1260-1266

32. Meschia G, Cotter JR, Makowski EL, Barron DH 1966 Simultaneous measurement of uterine and umbilical blood flows and oxygen uptakes. Q J Exp Physiol 52:1-18

33. Harding JE, Charlton VE, Evans PC 1992 Effects of beta-hydroxybutyrate infusion on hind limb metabolism in fetal sheep. Am J Obstet Gynecol 166:671-676

34. Clarke JT, Bier DM 1982 The conversion of phenylalanine to tyrosine in man. Direct measurement by continuous intravenous tracer infusions of L-[ring$2 \mathrm{H} 5]$ phenylalanine and $\mathrm{L}-[1-13 \mathrm{C}]$ tyrosine in the postabsorptive state. Metabolism 31:999-1005

35. Liechty EA, Boyle DW, Moorehead H, Lee WH, Bowsher RR, Denne SC 1996 Effects of circulating IGF-I on glucose and amino acid kinetics in the ovine fetus. Am J Physiol 271:E177-E185

36. Wolfe RR 1992 Radioactive and Stable Isotope Tracers in Biomedicine. Principles and Practice of Kinetic Analysis. Wiley-Liss, New York 
37. Tourian A, Goddard J, Puck TT 1969 Phenylalanine hydroxylase activity in mammalian cells. J Cell Physiol 73:159-170

38. Biolo G, Fleming RY, Maggi SP, Wolfe RR 1995 Transmembrane transport and intracellular kinetics of amino acids in human skeletal muscle. Am J Physio 268:E75-E84

39. Mortimore GE, Poso AR 1987 Intracellular protein catabolism and its control during nutrient deprivation and supply. Annu Rev Nutr 7:539-564

40. Hamel FG, Upward JL, Siford GL, Duckworth WC 2003 Inhibition of proteasome activity by selected amino acids. Metabolism 52:810-814

41. Bruins MJ, Soeters PB, Lamers WH, Deutz NE 2002 L-arginine supplementation in pigs decreases liver protein turnover and increases hindquarter protein turnover both during and after endotoxemia. Am J Clin Nutr 75:1031-1044
42. Shen W, Wisniowski P, Ahmed L, Boyle DW, Denne SC, Liechty EA 2003 Protein anabolic effects of insulin and IGF-I in the ovine fetus. Am J Physiol 284:E748-E756

43. Fowden AL 1989 The role of insulin in prenatal growth. J Dev Physiol 12:173-182

44. Charlton V, Johengen M 1985 Effects of intrauterine nutritional supplementation on fetal growth retardation. Biol Neonate 48:125-142

45. Charlton V, Johengen M 1987 Fetal intravenous nutritional supplementation ameliorates the development of embolization-induced growth retardation in sheep. Pediatr Res 22:55-61

46. Palmer RM, Ashton DS, Moncada S 1988 Vascular endothelial cells synthesize nitric oxide from L-arginine. Nature 333:664-666

47. Moncada S, Higgs EA 1995 Molecular mechanisms and therapeutic strategies related to nitric oxide. FASEB J 9:1319-1330 